J. Dairy Sci. 99:9631-9646

http://dx.doi.org/10.3168/jds.2016-11199

(C) 2016, THE AUTHORS. Published by FASS and Elsevier Inc. on behalf

of the American Dairy Science Association ${ }^{\circledR}$. This is an open access article under

the CC BY-NC-ND license (http://creativecommons.org/licenses/by-nc-nd/3.0/).

\title{
Cheesemaking in highland pastures: Milk technological properties, cream, cheese and ricotta yields, milk nutrients recovery, and products composition
}

\author{
M. Bergamaschi, ${ }^{*}$ C. Cipolat-Gotet, ${ }^{*}$ G. Stocco, ${ }^{*}$ C. Valorz, $†$ I. Bazzoli, $†$ E. Sturaro, ${ }^{* 1}$ M. Ramanzin, ${ }^{*}$ \\ and G. Bittante* \\ *Department of Agronomy, Food, Natural Resources, Animals and Environment (DAFNAE), University of Padova, Viale dell'Università 16, \\ 35020 Legnaro (PD), Italy \\ †Breeders Federation of Trento Province, via delle Bettine, 40, 38100 Trento, Italy
}

\begin{abstract}
Summer transhumance of dairy cows to high Alpine pastures is still practiced in many mountainous areas. It is important for many permanent dairy farms because the use of highland pastures increases milk production and high-priced typical local dairy products often boost farm income. As traditional cheese- and ricotta-making procedures in Alpine pastures are central to this dairy system, the objective of this study was to characterize the quality and efficiency of products and their relationships with the quality and availability of grass during the grazing season. The milk from 148 cows from 12 permanent farms reared on a temporary farm located in Alpine pastures was processed every 2 wk during the summer (7 cheesemakings from late June to early September). During each processing, 11 dairy products (4 types of milk, 2 by-products, 3 fresh products, and 2 ripened cheeses) were sampled and analyzed. In addition, 8 samples of fresh forage from the pasture used by the cows were collected and analyzed. At the beginning of the pasture season the cows were at $233 \pm 90 \mathrm{~d}$ in milk, $2.4 \pm 1.7$ parities, and produced $23.6 \pm 5.7 \mathrm{~kg} / \mathrm{d}$ of milk. The milk yield decreased with the move from permanent to temporary farms and during the entire summer transhumance, but partly recovered after the cows returned to the permanent farms. Similar trends were observed for the daily yields of fat, protein, casein, lactose, and energy, as we found no large variations in the quality of the milk, with the exception of the first period of Alpine pasture. The somatic cell counts of milk increased during transhumance, but this resulted from a concentration of cells in a lower quantity of milk rather than an increase in the total number of cells ejected daily from the udder. We noted a quadratic trend in availability of forage (fresh and dry matter
\end{abstract}

Received March 21, 2016.

Accepted August 8, 2016.

${ }^{1}$ Corresponding author: enrico.sturaro@unipd.it weight per hectare), with a maximum in late July. The quality of forage also varied during the summer with a worsening of chemical composition. The evening milk (before and after natural creaming), the whole morning milk, and the mixed vat milk had different chemical compositions, traditional coagulation properties, and curd-firming modeling parameters. These variations over the pasture season were similar to the residual variations with respect to chemical composition, and much lower with respect to coagulation and curdfirming traits. Much larger variations were noted in cream, cheese, and ricotta yields, as well as in nutrient recoveries in curd during the pasture season. The protein content of forage was correlated with some of the coagulation and curd-firming traits, the ether extract of forage was positively correlated with milk fat content and cheese yields, and fiber fractions of forage were unfavorably correlated with some of the chemical and technological traits. Traditional cheese- and ricottamaking procedures showed average cream, cheese, and ricotta yields of $6.3,14.2$, and $4.9 \%$, respectively, and an overall recovery of almost $100 \%$ of milk fat, $88 \%$ of milk protein, and $60 \%$ of total milk solids.

Key words: cow, transhumance, milk, cheese manufacture

\section{INTRODUCTION}

In addition to their economic function, mountain farms have an important role in many countries in terms of the preservation of landscape, conservation of historical traditions, and production of typical local products (Penati et al., 2011; Haddaway et al., 2013; Battaglini et al., 2014). One of the most distinctive and important traditional practices for both landscape preservation and typical local product manufacture is the summer transhumance of cows and small ruminants from permanent farms in the valleys to temporary farms in highland areas to exploit the Alpine pastures. This tradition still has particular significance in many 
mountainous areas of several European countries, especially the Alps region (Sturaro et al., 2013) where the making of typical cheeses on Alpine pastures allows the maximum benefits to be obtained from milk production. The quality of dairy products is closely connected with production conditions and the feeding strategies adopted (Bovolenta et al., 2009), and their fatty acid profiles are generally favorable to human health (Dewhurst et al., 2006; Ferlay et al., 2006; Coppa et al., 2011).

Some studies have shown that the botanical composition of pasture and the type of diet the cow is fed have an effect on the quality of milk and cheese (Agabriel et al., 1999; Ferlay et al., 2006; Romanzin et al., 2013). The importance of pasture as a key factor in the traceability and quality of dairy products has also been demonstrated (Martin et al., 2005, 2009; Buchin et al., 2006). However, few studies have been carried out on the evolution of the technological properties of milk during Alpine summer pasturing and the efficiency of traditional cheese production practices on temporary farms. Moreover, no information is available on byproducts of traditional cheesemaking, such as cream for butter production and ricotta from whey processing.

In light of this, a study on production efficiency and the relationships between dairy products derived from cheese- and ricotta-making in term of their physicochemical composition is of particular interest. The aim of our study was to investigate (1) the quality and technological properties of milk produced; (2) cream, cheese, and ricotta yields from traditional cheese making procedures; and (3) the qualitative characteristics of dairy products derived from cheese- and ricotta-making during the course of summer pasturing on a temporary highland farm.

\section{MATERIALS AND METHODS}

\section{Environmental Conditions and Pasture Characteristics}

The study was conducted from June to September on a temporary summer highland farm $(1,860 \mathrm{~m}$ above sea level) located in the northeastern part of the Italian Alps (Malga Juribello, Trento, Italy). The climate at the site is characterized by long, cold winters and warm, wet summers. The pasture was characterized by a high biodiversity and the prevalent pasture type was a typical Nardetum alpigenum association, which has replaced the native woodland and shrub land as a result of continuous human and animal action (Orlandi et al., 2000). The feeding strategy was pasture-based and the cows were free to graze day and night. The pastures covered a total of 180 ha and the herd was composed of 148 cows, on average; the herd was moved to different areas of the pasture according to grass availability without a rigid rotation.

\section{Grass Availability and Composition}

Every 2 wk on the day before experimental cheesemaking, the grass available in the pasture sections grazed by cows was sampled by cutting the grass in 8 sites of $1 \times 1 \mathrm{~m}$ at an approximate height of $3 \mathrm{~cm}$ from the ground. Samples were weighed and a fixed proportion of each was pooled into a composite sample of the 8 sites, representing the grass available to the cows on a given date. The proportions varied on the different sampling dates to obtain composite samples weighing about $2 \mathrm{~kg}$.

The composite samples were frozen and stored at $-20^{\circ} \mathrm{C}$ until chemical analysis at the laboratory of the Department of Agronomy, Food, Natural resources, Animals and Environment (DAFNAE) of the University of Padova (Legnaro, Italy). The content of DM, $\mathrm{CP}$, ether extract, NDF, ADF, acid detergent lignin, and ash of the composite samples were analyzed in duplicate using the methods of AOAC International (2000) and the Van Soest et al. (1991) procedure.

During the experiment, the grazing cows were given a supplement of compound feed $(5.0 \pm 1.5 \mathrm{~kg} / \mathrm{d})$, which included a mixture of corn, wheat barn, soybean meal, and molasses of sugarcane distributed twice daily in the milking parlor according to milk yield. The compound feeds were sampled and analyzed in duplicate.

\section{Animals and Milking}

A total of 148 dairy cows were moved to Malga Juribello (Italy) from 12 permanent farms located in the province of Trento. The main characteristics of these farms and cows are given in Table 1. The farms represented mainly traditional farming systems (Sturaro et al., 2013), with tiestalls and feeding based on hay and compound feeds, although a few farms and cows from modern dairy systems were present. Cow breeds were mainly Brown Swiss (75.0\%), dual-purpose Simmental (18.2\%), and crossbreeds, with only a few head of Rendena and Holstein-Friesian. The mean and standard deviation of the cows' DIM, parity, and milk yield on their move to the summer pastures are shown in Table 1 . This table clearly shows that the animals were prevalently multiparous lactating cows in the second half of lactation. Some of the permanent farms produced milk for traditional cheese making according to European Union Protected Designation of Origin (PDO) criteria, whereas others produced milk for processing into fresh cheese, fluid milk, and other dairy products. 
Malga Juribello's modern milking parlor, similar to many others on temporary summer farms in the area, was housed in the old barn where in the past the cows were kept tied overnight. The cows were milked twice daily at roughly 12 -h intervals (0400 and $1600 \mathrm{~h}$ ).

\section{Sampling}

A description of the samples or data of milk, dairy products, and grass examined in this experiment is shown in Supplemental Table S1 (http://dx.doi. org/10.3168/jds.2016-11199). Individual milk samples were collected from 148 cows before (permanent farm/ June), during (temporary farm/early July; late July; early August; late August), and after (permeant farm/ September) summer transhumance to highland pasture and analyzed for productive traits (milk yield, fat, protein, casein, lactose, SCC). Moreover, individual milk recording data (fat, protein, casein, lactose) carried out in the temporary summer farm, Malga Juribello, during the 8 yr before the trial were collected and analyzed for comparison with year of experiment. Seven series of 4 types of bulk milk (evening whole milk, skimmed evening milk, morning whole milk, milk vat), cream, fresh cheese, whey, ricotta, scotta (residual liquid), and ripened cheese for 6 and 12 mo during summer transhumance (from June to September) were sampled during experimental cheese- and ricotta-making performed every 2 wk and analyzed for physicochemical composition. Last, the day before each cheese- and ricotta-making, 8 areas representative of the pasture were selected and the grass present on $1 \mathrm{~m}^{2}$ per area was cut, collected, weighed, sampled, and mixed to obtain composite samples used for chemical analyses of grass.

\section{Cheesemaking and Ricotta-Making}

Malga Juribello has a small dairy that was used for making experimental cheeses every 2 wk according to the following procedure. Raw milk (250 L) from the evening milking was collected in an open tank and maintained at about $15^{\circ} \mathrm{C}$ overnight to permit partial spontaneous fat creaming. The following morning, the cream was removed from the surface and the skim milk transferred to the vat and mixed with $250 \mathrm{~L}$ of fresh morning milk. The evening whole milk, cream, evening skim milk, morning whole milk, and mixed milk in the vat were sampled. The $500 \mathrm{~L}$ of mixed milk was heated in the vat to $27^{\circ} \mathrm{C}$ and inoculated with $250 \mathrm{~g}$ of fullfat yogurt composed of pasteurized milk, Streptococcus thermophilus, and Lactobacillus bulgaricus (Latte Trento, Trento, Italy). After about $1 \mathrm{~h}$ of incubation, $25 \mathrm{~g}$ of commercial rennet [Naturen extra 1,030 NB, 1,030 international milk clotting units (IMCU)/g] diluted in $550 \mathrm{~mL}$ of water (final rennet dilution $=51.5$ IMCU/L of milk) was added to the milk. Clotting time was about $15 \mathrm{~min}$ and detected visually. Firm coagulum was manually cut (with a lira) into pellets the size of rice grains. After cutting, the curd in the vat was turned to facilitate draining and then cooked at 44 to $45^{\circ} \mathrm{C}$ for 15 min. Finally, the curd was separated and sampled then put into cylindrical molds $(30 \mathrm{~cm}$ diameter $\times 12$ $\mathrm{cm}$ height) and pressed for $20 \mathrm{~h}$, during which time it was turned 2 to 3 times to facilitate draining. The following day, the fresh cheeses were salted by placing in brine $(16 \% \mathrm{NaCl})$ for $80 \mathrm{~h}$. They were then ripened for 6 and $12 \mathrm{mo}$ in a ripening cellar until analysis. The temperature in the cellar was about $12^{\circ} \mathrm{C}$ and the relative humidity was $85 \%$.

The whey remaining from cheesemaking was sampled and used to produce ricotta. Briefly, $200 \mathrm{~L}$ of whey was transferred into a small vat and heated to $90^{\circ} \mathrm{C}$, and then $750 \mathrm{~mL}$ of wine vinegar was added to catalyze the thermo-acid coagulation. The ricotta was removed from the vat, weighed, sampled, and placed in molds to allow it to cool and the scotta to drain. The scotta was also sampled. The cream, curd, whey, ricotta, and scotta

Table 1. Descriptive statistics of permanent farms and of production traits of cows (mean \pm SD) at the beginning of Alpine pasture season

\begin{tabular}{|c|c|c|c|c|c|c|c|c|c|}
\hline $\begin{array}{l}\text { Permanent } \\
\text { farm }\end{array}$ & $\begin{array}{c}\text { Altitude, } \\
\text { m above sea } \\
\text { level }\end{array}$ & Housing & TMR & $\begin{array}{c}\text { Cows, } \\
\text { No. }\end{array}$ & Breed $^{1}$ & DIM & Parity & $\begin{array}{l}\text { Milk yield, } \\
\mathrm{kg} / \mathrm{d}\end{array}$ & $\begin{array}{l}\text { Milk for } \\
\text { Protected } \\
\text { Designation of } \\
\text { Origin }\end{array}$ \\
\hline 1 & 980 & Loose & No & 8 & BS & $345 \pm 105$ & $2.0 \pm 1.6$ & $22.8 \pm 2.7$ & Yes \\
\hline 2 & 892 & Tied & No & 20 & BS; HF; CB; SI & $206 \pm 75$ & $1.9 \pm 1.2$ & $22.2 \pm 5.5$ & No \\
\hline 3 & 688 & Loose & No & 40 & $\mathrm{BS}$ & $245 \pm 75$ & $2.0 \pm 1.2$ & $27.5 \pm 4.3$ & Yes \\
\hline 4 & 178 & Tied & No & 9 & BS; CB; SI & $265 \pm 114$ & $2.1 \pm 2.5$ & $20.9 \pm 4.2$ & Yes \\
\hline 7 & 1,030 & Loose & No & 9 & BS; HF & $283 \pm 93$ & $1.5 \pm 2.1$ & $25.5 \pm 4.7$ & No \\
\hline 8 & 150 & Tied & Yes & 25 & BS & $218 \pm 102$ & $2.9 \pm 1.7$ & $20.0 \pm 6.3$ & No \\
\hline $9^{2}$ & $669-1,343$ & Tied & No & 18 & BS; HF; CB; SI; RE & $210 \pm 99$ & $3.5 \pm 1.6$ & $22.8 \pm 6.7$ & Yes \\
\hline Total & $798 \pm 366$ & - & - & 148 & - & $233 \pm 90$ & $2.4 \pm 1.7$ & $23.6 \pm 5.7$ & - \\
\hline
\end{tabular}

${ }^{1} \mathrm{BS}=$ Brown Swiss; HF = Holstein-Friesian; CB = Crossbreed; SI = Simmental; RE = Rendena.

${ }^{2}$ This is a cluster composed of 4 small herds. 


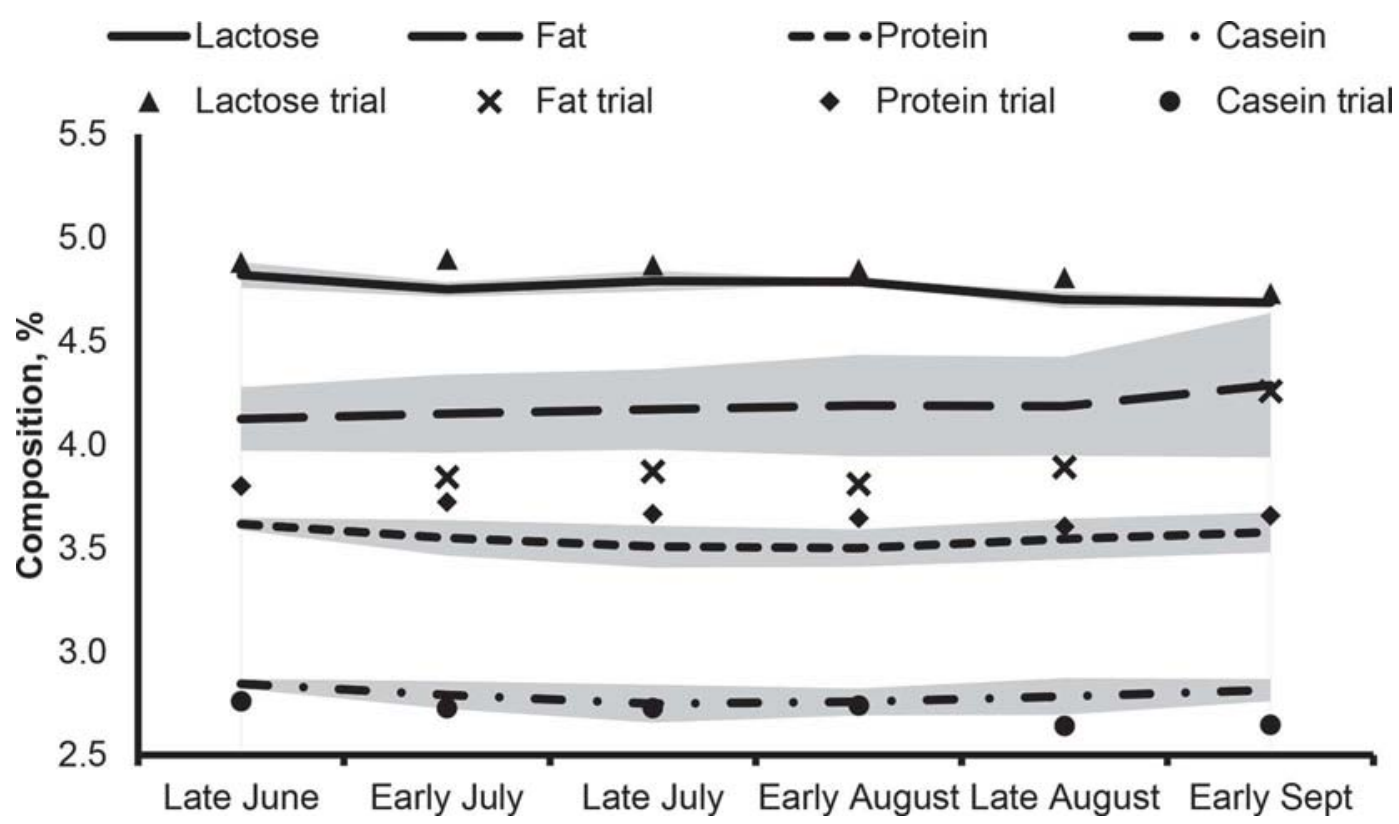

Figure 1. Evolution of milk composition during summer pasture in the $8 \mathrm{yr}$ before trial (the lines represent the mean content and the gray area the interval between mean \pm SD for each chemical component) and in the year of the trial (individual point indicators for each component) according to the milk recording data carried out in the temporary summer farm.

samples, as well as the milk samples, were stored in a freezer $\left(-20^{\circ} \mathrm{C}\right)$ until analysis was performed, within 1 mo.

\section{Milk and Cheese Analysis}

Analyses of the chemical and physical traits of the 7 complete series, of milk, cream, whey, ricotta, scotta, curd, and cheese samples collected during summer transhumance were performed at the DAFNAE milk laboratory. Fat, protein, and casein percentages were determined by infrared analysis (MilkoScan FT2, Foss Electric A/S, Hillerød, Denmark). Somatic cell count were obtained with a Fossomatic FC automatic cell counter (Foss) then converted to SCS by logarithmic transformation (Ali and Shook, 1980). The $\mathrm{pH}$ was measured with a Crison Basic 25 electrode (Crison Instruments SA, Barcelona, Spain). The chemical composition of the curd, ricotta, and cheese was measured using a FoodScan (Foss); cheeses were analyzed at 6 and $12 \mathrm{mo}$ of ripening. The variations in daily yield and quality traits of milk of each individual cow obtained from individual milk recording program before transportation to the summer temporary farm, during summer transhumance, and after the return of the cows to the permanent farm are discussed in the results. In addition, the evolution of milk gross composition during summer pasture in the $8 \mathrm{yr}$ before trial is shown in Figure 1; an overview of the productive traits of the cows was obtained classifying the dates of recording in 6 fortnight periods and obtaining the corresponding mean value and standard deviation for each considered trait. The data were provided by the Breeders Federation of Trento Province (Trento, Italy).

\section{Milk Coagulation Properties, Yields, and Nutrient Recoveries of Cheese, Ricotta, and Cream}

In this study we used the traditional parameters of milk coagulation properties [rennet coagulation time (RCT), curd-firming time of samples reaching $20 \mathrm{~mm}$ of firmness within $45 \mathrm{~min}$ of enzyme addition $\left(\mathbf{k}_{\mathbf{2 0}}\right)$, and curd firmness 30 min after enzyme addition $\left(\mathbf{a}_{\mathbf{3 0}}\right)$ ] reported by McMahon and Brown (1982), and the curd firming and syneresis modeling parameters [RCT estimated through trough individual curd-firming equation $\left(\mathrm{RCT}_{\text {eq }}\right)$, potential asymptotical curd firmness in absence of syneresis $\left(\mathrm{CF}_{\mathrm{P}}\right)$, curd-firming instant rate constate $\left(\mathrm{k}_{\mathrm{CF}}\right)$, curd syneresis instant rate constant $\left(\mathrm{k}_{\mathrm{SR}}\right)$, maximum curd firmness value $\left(\mathrm{CF}_{\max }\right)$, and time at $\left.\mathrm{CF}_{\max }\left(\mathrm{t}_{\max }\right)\right]$ proposed by Bittante (2011) and Bittante et al. (2013) to measure the coagulation parameters of the 4 types of bulk milk (evening whole, evening after creaming, morning whole, and mixture vat).

Cheese yields and nutrient recoveries were obtained considering 7 cheesemaking processes according to the procedure described in detail by Cipolat-Gotet et al. (2013) for model cheesemaking. The yields and nutrient recoveries of the ricotta and cream were similarly obtained. 


\section{Statistical Analysis}

Statistical analysis was performed using SAS (SAS Institute Inc., Cary, NC). All the dairy product physicochemical composition data were processed using mixed model analyses of variance according to the following model:

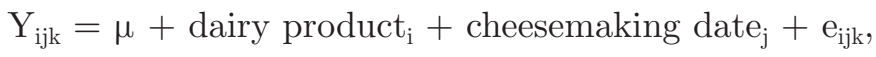

where $y_{i j k}$ is the measured physicochemical traits of the dairy product; $\mu$ is the overall mean; dairy product $t_{i}$ is the fixed effect of the $i$ th dairy product ( $\mathrm{i}=1$ to 11 ); cheesemaking date ${ }_{j}$ is the random effect of the $j$ th day of cheese making ( $\mathrm{k}=1$ to 7 ); and $\mathrm{e}_{\mathrm{ijk}}$ is the residual random error term $\sim N\left(0, \sigma^{2}\right)$, where $\sigma^{2}$ is the residual variance. The same model, without dairy product and with cheesemaking date as fixed factor, was used for forage (mass and chemical composition), and with individual milk recording date for individual cow milk yield and quality before, during, and after summer transhumance. In addition, orthogonal contrasts were used to compare the least squares means of the different products obtained and the seasonal variations in yields and nutrient recoveries. The grass chemical composition, milk gross composition, yields, and nutrient recoveries of the last 2 cheesemakings (early September) with similar least squares means were averaged.

\section{RESULTS AND DISCUSSION}

\section{Alpine Pasture Productivity and Quality}

The availability of grass in the Alpine pasture, expressed as tonnes of fresh grass per hectare, increased greatly from the beginning of the grazing season in mid-June (1.99 t/ha) until August (3.82 t/ha), and de- creased thereafter to a very low level $(1.91 \mathrm{t} / \mathrm{ha})$ at the end of the grazing season in mid-September (data not shown). The vegetative period in this area is shorter in comparison with the plains, with a consequent decrease of biomass (t/ha) in the late summer. The evolution of available DM followed a similar, although less marked, pattern, confirming the results obtained by Bovolenta et al. (1998, 2002).

The chemical composition and nutritional value of grass and the supplementary compound feeds is provided in Table 2. The quality of grass varied considerably during the grazing season, with increases in DM (24.3 to $34.1 \%$ ), NDF (43.4 to $50.8 \% \mathrm{DM}$ ), $\mathrm{ADF}$ (21.9 to $26.6 \% \mathrm{DM}$ ), and ADL (3.2 to $5.3 \% \mathrm{DM}$ ) and a decrease in CP (16.8 to $11.4 \%$ DM; Figure 2). The fat content of the compound feed was higher during the latter part of summer grazing than during the earlier part to take into account the decrease in the digestibility of the grass.

\section{Milk Yield and Quality Before, During, and After Summer Transhumance}

Table 3 reports the variations in daily yield and quality traits of milk produced before, during, and after summer transhumance. We noted a strong reduction $(-21 \%)$ in milk yield after moving from permanent farms to summer pastures, which could be due to increased stress in the animals in reaction to very different environmental and feeding conditions. Milk yield during the grazing season was almost constant during the first phase (July), but further decreased by about $15 \%$ during the second phase (August); this pattern is consistent with the effects of advancing pregnancy. We observed a positive effect on milk yield of returning to the permanent farms $(+10 \%)$. The effect of grazing

Table 2. Descriptive statistics and ANOVA of forage mass and chemical composition, sampled every 2 wk during summer transhumance the day before experimental cheese-making $(\mathrm{n}=7)$ by cutting the grass in 8 sites of $1 \times 1 \mathrm{~m}$, and descriptive statistics of compound feeds used during the trial

\begin{tabular}{|c|c|c|c|c|c|c|c|c|c|}
\hline Item & \multicolumn{2}{|c|}{ Pasture } & \multicolumn{3}{|c|}{ Summer variation ( $P$-value) } & \multicolumn{2}{|c|}{ Root means square } & \multicolumn{2}{|c|}{ Compound feed ${ }^{1}$} \\
\hline DM of grass, $\%$ & 29.54 & 3.89 & $* * *$ & $* * *$ & $* * *$ & 5.50 & 0.06 & - & - \\
\hline \multicolumn{10}{|l|}{ Grass, \% of DM } \\
\hline $\mathrm{CP}$ & 12.65 & 2.00 & $* * *$ & $* * *$ & $* * *$ & 2.83 & 0.33 & 14.27 & 14.72 \\
\hline $\mathrm{ADF}$ & 25.36 & 2.15 & $* * *$ & NS & $* * *$ & 3.04 & 0.36 & 9.93 & 9.14 \\
\hline ADL & 4.52 & 0.88 & $* * *$ & NS & $* * *$ & 1.24 & 0.10 & 1.51 & 1.66 \\
\hline Ash & 7.71 & 0.56 & $* * *$ & NS & $* *$ & 0.79 & 0.16 & 8.97 & 8.09 \\
\hline
\end{tabular}

${ }^{1}$ Compound feed $=$ the first period was from late June to early August, whereas the second period was from late August to early September. ${ }^{* *} P<0.01 ; * * * P<0.001$. 


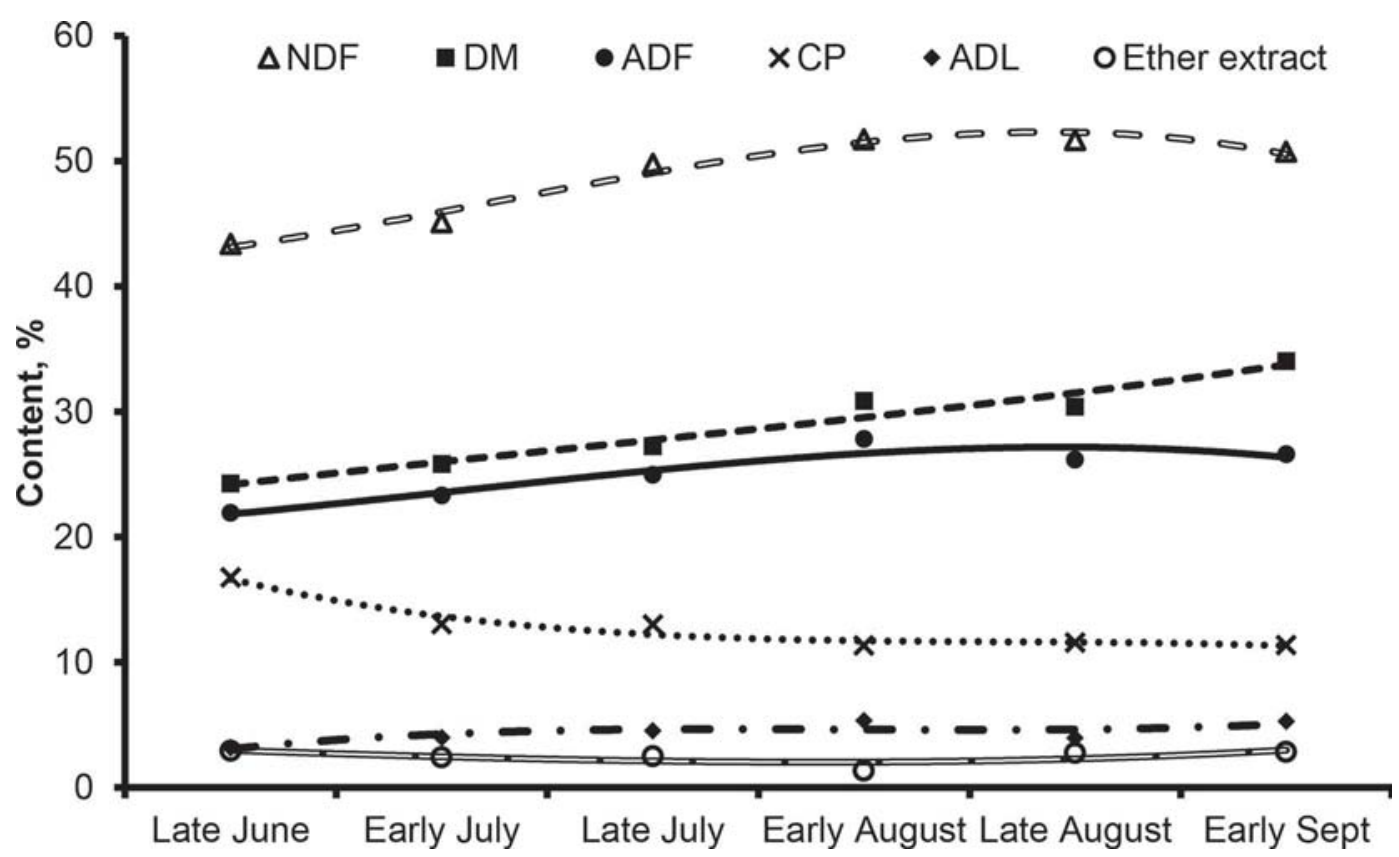

Figure 2. Average content of DM (\% of fresh weight), CP (\% of DM), ether extract (fat, \% of DM), NDF (\% of DM), and ADF (\% of DM) of grass in the areas of the Alpine summer pasture grazed by the dairy cows used for experimental cheese- and ricotta-making.

season on milk yield was statistically significant $(P<$ $0.001)$.

A very similar pattern was observed by Leiber et al. (2006) in mid-lactation Brown Swiss cows moved to high altitude pastures in Switzerland, with a decrease of $27 \%$ in ECM yield after moving from lowland to highland pastures, and $-10 \%$ during summer pastur- ing, although they did not observe production recovery after the cows returned to lowland pastures. Zendri et al. (2016a) monitored milk production on 15 temporary farms in the same area as the present study and observed a smaller negative effect $(-10 \%)$ of moving lactating cows to summer pastures, but a greater decrease in milk yield $(-43 \%)$ during the grazing season and a

Table 3. Descriptive statistics (mean $\pm \mathrm{SD}$ ) of individual milk recording data before, during, and after summer transhumance to alpine pasture

\begin{tabular}{|c|c|c|c|c|c|c|}
\hline \multirow[b]{2}{*}{ Traits } & \multirow{2}{*}{$\begin{array}{c}\begin{array}{c}\text { Permanent } \\
\text { farm }\end{array} \\
\text { June }\end{array}$} & \multicolumn{4}{|c|}{ Summer Alpine pasture (temporary farm): } & \multirow{2}{*}{$\begin{array}{c}\begin{array}{c}\text { Permanent } \\
\text { farm }\end{array} \\
\text { September }\end{array}$} \\
\hline & & Early July & Late July & Early August & Late August & \\
\hline Lactating cows, no. & 148 & 148 & 148 & 130 & 119 & 109 \\
\hline \multicolumn{7}{|l|}{ Productive traits } \\
\hline Milk yield, kg/d & $23.6 \pm 5.7$ & $18.7 \pm 5.2$ & $18.5 \pm 5.4$ & $17.7 \pm 4.9$ & $16.0 \pm 4.9$ & $17.6 \pm 6.3$ \\
\hline Lactose, $\mathrm{kg} / \mathrm{d}$ & $1.16 \pm 0.29$ & $0.89 \pm 0.26$ & $0.89 \pm 0.27$ & $0.85 \pm 0.25$ & $0.74 \pm 0.24$ & $0.84 \pm 0.31$ \\
\hline Energy, MJ/d & $73.9 \pm 17.4$ & $60.9 \pm 14.3$ & $57.6 \pm 15.7$ & $55.6 \pm 13.3$ & $48.7 \pm 13.2$ & $55.3 \pm 18.9$ \\
\hline $\mathrm{SCY}, \mathrm{U} / \mathrm{d}$ & $30.9 \pm 1.7$ & $31.2 \pm 1.4$ & $31.2 \pm 1.5$ & $31.3 \pm 1.5$ & $30.9 \pm 1.5$ & $30.7 \pm 1.7$ \\
\hline \multicolumn{7}{|l|}{ Milk composition } \\
\hline Fat, $\%$ & $3.82 \pm 0.60$ & $4.29 \pm 0.67$ & $3.90 \pm 0.55$ & $3.94 \pm 0.80$ & $3.80 \pm 0.63$ & $3.86 \pm 0.76$ \\
\hline Protein, \% & $3.72 \pm 0.37$ & $3.74 \pm 0.32$ & $3.64 \pm 0.35$ & $3.77 \pm 0.43$ & $3.75 \pm 0.41$ & $3.87 \pm 0.52$ \\
\hline Fat:protein & $1.04 \pm 0.19$ & $1.15 \pm 0.16$ & $1.07 \pm 0.13$ & $1.05 \pm 0.19$ & $1.02 \pm 0.14$ & $1.01 \pm 0.21$ \\
\hline
\end{tabular}

${ }^{1} \mathrm{SCY}=\log _{2}(\mathrm{SCC} \times$ milk yield $\times 1,000)$.

${ }^{2} \mathrm{SCS}=\log _{2}(\mathrm{SCC} / 100,000)+3$. 
higher recovery $(+26 \%)$ after return to the permanent farms. The differences between this and the pattern observed in the present study can be partly explained by the different breed compositions of the herds. In the present work the cows were mainly Brown Swiss and dual-purpose breeds, which in the study of Zendri et al. (2016a) presented a lower negative effect of summer transhumance on milk yield than the Holstein-Friesians.

Some variations in milk quality were also found during the trial (Table 3). In particular, we noted a marked increase in milk fat content $(P<0.001)$ after the cows were moved to the summer pastures, concomitant with a substantial reduction in milk yield, resulting in a much smaller decrease in daily milk fat yield $(P<$ 0.001). On the other hand, summer transhumance had little effect on the milk protein $(P<0.001)$ and casein content $(P<0.01)$, with daily production decreasing at a rate similar to that observed for milk yield. An increase in milk fat content and relative stability of the milk protein and casein contents were also observed by Leiber et al. (2006), but not by Zendri et al. (2016a).

Lactose content of milk decreased $(P<0.001)$ at the beginning of summer pasture concomitant with an increase in SCS $(P<0.001)$. Decrease of lactose content and the increase of SCS after moving to summer temporary farms were observed also in the survey led by Zendri et al. (2016a), whereas Leiber et al. (2006) found only a decrease in lactose without the parallel increase in SCS. In the current study, the increased SCS was probably mainly due to a concentration of somatic cells as a result of the decrease in daily milk yield rather than an increase in the incidence of subclinical mastitis, as the daily excretion of somatic cells with milk increased only marginally during summer transhumance $(P<0.05)$.

Taking the observed variations in qualitative traits together, the energy content of milk was estimated (NRC, 2001) to increase by about $5 \%$ soon after arrival at the Alpine pasture and subsequently to return to the previous values $(P<0.001$; Table 3$)$. The daily output of milk energy, however, decreased by $18 \%$ after moving the cows to Alpine pastures, and by a further $20 \%$ during summer grazing to recover by $14 \%$ after returning to the permanent farms $(P<0.001$; Table 3$)$.

Variations in milk composition during summer grazing also depend on contemporaneous variation in the quantity and quality of the available grass (Buchin et al., 1999; Collomb et al., 2002; Gorlier et al., 2012). Although the present study was not designed to quantify fresh forage intake and composition, it was possible to get some indication of the relationship between the cows' feeding regimen and their production levels by examining Pearson correlations between the quantity and quality of forage available in the grazed area and milk composition (Table 4).

Regarding milk composition, we found a tendency toward an unfavorable relationship between the quantity of forage DM available in the Alpine pastures grazed by the cows and the milk fat and TS contents (Table 4). The quality of forage, too, affected milk composition, as there was a strong positive correlation between the lipid content of grass and that of milk and of milk TS.

The values of the milk quality traits recorded during the trial were compared with those measured over the previous $8 \mathrm{yr}$ in the same summer farm (Figure 1). Lactose and casein contents were similar, whereas fat content was smaller and protein content greater during the trial than in the previous years.

\section{Milk Composition, Coagulation Time, Curd Firming, and Syneresis}

The traditional procedure used on temporary Alpine farms (malga in Italian) to produce Malga cheeses involves several steps. The evening milk is kept for naturally creaming overnight. Then, the next day this skim milk is mixed in the cheese vat with the morning milk. The chemical composition of these 4 types of bulk milk and the variations recorded between 7 different cheesemaking dates are presented in Table 5 .

Gravity separation of the cream from the evening milk (creaming effect) not only reduces the milk fat $(-38 \%)$ and TS $(-10 \%)$ contents, but slightly concentrates its casein $(+4 \%)$ and lactose $(+3 \%)$ contents. In addition, the main effect of creaming is a sizeable reduction in the somatic cell content of the evening milk, on both logarithmic (SCS: -70\%) and linear (SCC: -83\%) scales. The gravity separation could be influenced by the level of bacteria in the milk before separation, time, and temperature (Caplan et al., 2013). Bovine immunoglobulins are involved in the process of agglutination and clustering of milk fat globules, and may also contribute to the gravity separation of bacteria and somatic cells (Euber and Brunner 1984; Caplan et al., 2013). A high somatic cell content can reduce cheese yield and increases lipolysis and proteolysis activity in whole milk and yogurt (Politis and Ng-Kwai-Hang, 1988); natural creaming is also used in the production of hard cheeses from raw milk as a way of removing antidairy microbes, especially clostridia, that can cause late blowing of cheeses (Bertoni et al., 2001; Caplan et al., 2013; Feligni et al., 2014).

The milk from the morning milking had a higher content of fat $(+6 \%)$, lactose $(+1.5 \%)$, TS $(+2 \%)$, and especially somatic cells (SCS: $+25 \%$; SCC: $+88 \%$ ) than the milk obtained the previous evening. Mixing 
the whole milk of the morning with the skim milk of the previous evening resulted in a significant deviation from the expected values (average of the 2 milks) only for SCS $(+29 \%)$, but this deviation is only apparent due to the logarithmic nature of the trait; in fact, the expected value in logarithmic terms is 3.66 , very close to the observed value of 3.59 .

The lactodynamographic properties of milk are also presented in Table 5. Natural creaming had no effect on traditional coagulation properties and on the modeling parameters of curd firming and syneresis. Stocco et al. (2015) also observed a very small effect of natural creaming on lactodynamographic traits in milk destined for the production of Grana Padano cheese. It is worth noting that morning milk, in contrast to evening milk, was characterized by an accelerated pattern of coagulation curd firming and syneresis, leading to lower potential curd firmness at infinite time and lower measured maximum curd firmness, even if attained earlier. Mixing creamed evening milk with morning milk was unfavorable for curd firmness (Table 5), as this resulted in a mixture in the cheese-vat intermediate between the 2 components in terms of coagulation time and $\mathrm{k}_{20}$, but lower in terms of $\mathrm{a}_{30}$ (Table 5). Curd-firming modeling revealed that both instant rate constants (curd firming and syneresis) were greater than the average of the 2 components and more similar to those of the whole morning milk, which explains the observed lower potential and maximum curd firmness.

The root mean squares of cheesemaking date and of error of all traits are shown in Table 5. These reveal that the variability brought about by advancing grazing season is similar to that characterizing residual variability in the case of all milk quality traits (SCS excepted), whereas it is about half in the case of traditional milk-coagulation properties and even lower for curd-firming modeling parameters. In particular, RCT $(P<0.001), \mathrm{k}_{20}(P<0.01)$, and $\mathrm{a}_{30}(P<0.01)$ were highly influenced by summer transhumance.

On average, RCT was good (measured both as a single point and on the basis of curd-firming modeling), and was shorter than that of milk from Brown Swiss cows reared in permanent mountain farms in the same province (Cecchinato et al., 2013). The other 2 traditional traits $\left(\mathrm{k}_{20}\right.$ and $\left.\mathrm{a}_{30}\right)$ were also more favorable for milk obtained during summer transhumance. In a trial under similar Alpine conditions, Bovolenta et al. (2009) recorded less favorable traditional coagulation properties than in the present study, but they found that these traits depended on the quantity of compound feed administered to cows on Alpine pastures. A more analytical approach based on modeling all the information

Table 4. Pearson correlations between quantity and quality of the grass available in the Alpine pasture the day before each experimental cheesemaking and the milk composition, coagulation and curd firming properties of bulk milk used for seven cheese-makings

\begin{tabular}{|c|c|c|c|c|}
\hline \multirow[b]{2}{*}{ Item } & \multirow{2}{*}{$\frac{\text { Grass available, t/ha }}{\mathrm{DM}}$} & \multicolumn{3}{|c|}{ Grass composition, $\%$ of DM } \\
\hline & & $\mathrm{CP}$ & Ether extract & $\mathrm{NDF}$ \\
\hline \multicolumn{5}{|c|}{ Milk composition } \\
\hline Fat, \% & -0.72 & 0.36 & $0.91^{* * *}$ & -0.19 \\
\hline Protein, $\%$ & -0.52 & 0.43 & 0.17 & -0.64 \\
\hline Lactose, \% & 0.14 & 0.30 & -0.24 & -0.42 \\
\hline TS; \% & -0.71 & 0.56 & 0.73 & -0.54 \\
\hline \multirow{2}{*}{\multicolumn{5}{|c|}{$\mathrm{MCP}^{2}$}} \\
\hline & & & & \\
\hline $\mathrm{RCT}, \min$ & 0.68 & $-0.89^{* *}$ & -0.51 & $0.79^{*}$ \\
\hline $\mathrm{k}_{20,} \min$ & 0.48 & -0.58 & -0.03 & $0.78^{*}$ \\
\hline $\mathrm{a}_{30}, \mathrm{~mm}$ & -0.47 & 0.63 & 0.15 & $-0.88^{* *}$ \\
\hline \multicolumn{5}{|l|}{$\mathrm{CF}_{\mathrm{t}}$ modeling ${ }^{3}$} \\
\hline $\mathrm{RCT}_{\mathrm{eq}}, \min$ & 0.67 & $-0.93^{* *}$ & -0.36 & $0.88^{* *}$ \\
\hline $\mathrm{CF}_{\mathrm{P}}, \mathrm{mm}$ & -0.66 & 0.65 & 0.15 & $-0.90^{* *}$ \\
\hline $\mathrm{k}_{\mathrm{CF}}, \min ^{-1}$ & 0.39 & $-0.76^{*}$ & -0.08 & $0.95^{* * *}$ \\
\hline $\mathrm{k}_{\mathrm{SR}}, \min ^{-1}$ & 0.37 & -0.65 & 0.02 & $0.87^{* *}$ \\
\hline $\mathrm{CF}_{\max }, \mathrm{mm}$ & -0.44 & 0.65 & 0.15 & $-0.91^{* *}$ \\
\hline $\mathrm{t}_{\max }, \min$ & -0.44 & $0.74^{*}$ & 0.14 & $-0.95^{* *}$ \\
\hline
\end{tabular}

${ }^{1} \mathrm{SCS}=\log _{2}(\mathrm{SCC} / 100,000)+3$.

${ }^{2} \mathrm{MCP}=$ milk coagulation properties; $\mathrm{RCT}=$ rennet coagulation time of samples coagulating within 45 min from enzyme addition; $\mathrm{k}_{20}=$ curd-firming time of samples reaching $20 \mathrm{~mm}$ of firmness within $45 \mathrm{~min}$ from enzyme addition; $\mathrm{a}_{30}=$ curd firmness 30 min after enzyme addition.

${ }^{3} \mathrm{CF}_{\mathrm{t}}$ modeling = modeling of the 180 curd firmness observations collected for each milk sample; $\mathrm{CF}_{\mathrm{P}}=$ potential asymptotical curd firmness in absence of syneresis; $\mathrm{k}_{\mathrm{CF}}=$ curd firming instant rate constant; $\mathrm{k}_{\mathrm{SR}}=$ curd syneresis instant rate constant; $\mathrm{RCT}_{\mathrm{eq}}=$ rennet coagulation time estimated through individual curd firming equation; $\mathrm{CF}_{\max }=$ maximum curd firmness value; $\mathrm{t}_{\max }=$ time at $\mathrm{CF}_{\max }$.

${ }^{*} P<0.05$; ${ }^{* *} P<0.01$; *** $P<0.001$. 
from the lactodynamograph revealed potential curd firmness and the instant rate constant of curd firming to be similar in milk from Alpine pastures (present study) and milk from permanent farms (Bittante et al., 2015). The syneresis instant rate constant differed, however, and was much slower in milk from the Alpine pastures, which explains the greater maximum curd firmness attained, even over similar time intervals. In Figure 3, it is possible to note a faster coagulation of morning whole milk than the other types of milk. Nevertheless, the curd firmness of whole morning milk was lower than whole evening milk and evening milk after creaming. On average, the milk in vat (mixture) presents less curd firmness in terms of potential asymptotical curd firmness $\left(\mathrm{CF}_{\mathrm{p}}=52.0 \mathrm{~mm}\right)$ and maximum curd firmness value $\left(\mathrm{CF}_{\max }=44.0 \mathrm{~mm}\right)$. Moreover, this type of milk was characterized by a high curd-firming instant rate $\left(\mathrm{k}_{\mathrm{CF}}=17.0 \mathrm{~min}^{-1}\right)$ and curd syneresis instant rate $\left(\mathrm{k}_{\mathrm{SR}}\right.$ $=0.92 \mathrm{~min}^{-1}$ ) than the other 3 types of milk (Table 5). It should be pointed out that curd-firming parameters, and especially potential and maximum curd firmness, are related phenotypically and genetically to cheese yield (Cecchinato and Bittante, 2016).
Milk coagulation properties were highly affected by grass quality as they were all unfavorably related to fiber content (NDF), whereas coagulation time was favorably related to grass protein content (Table 4).

\section{Cream, Cheese, and Ricotta Yields and Nutrients Recovery}

Cream, cheese, and ricotta yields obtained according to traditional cheesemaking procedures on the temporary summer Alpine farm are given in Table 6 together with the nutrient recoveries of each phase. We found average cream, cheese, and ricotta yields of $6.3 \%$ of whole milk, $14.2 \%$ of milk in vat, and $4.9 \%$ of whey, respectively. Quantitative data obtained from Alpine pastures are very scarce, but these results are comparable to those obtained, albeit in different conditions, by Martin et al. (2009) and Cipolat-Gotet et al. (2013) for cheesemaking and by Pintado et al. (2001) for ricotta making.

As shown in Figure 4a, the patterns during summer transhumance were toward a slight increase for ricotta yield (cubic, from 4.65 to $5.60 \%$ ) and a decrease for

Table 5. Composition and technological traits of bulk milk used for 7 cheesemakings during summer transhumance

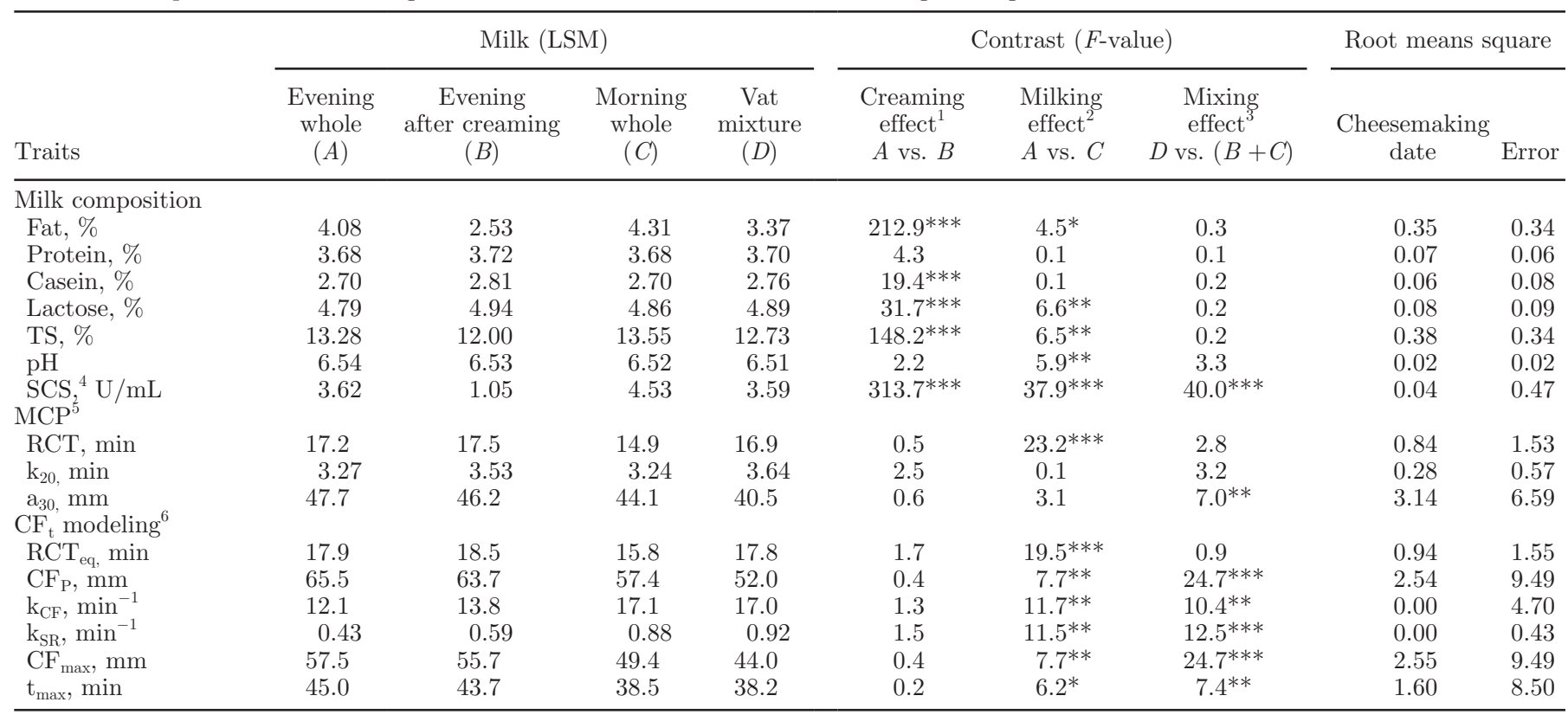

${ }^{1}$ Contrast between the whole milk of the evening milking vs. the same milk the following morning after natural creaming overnight.

${ }^{2}$ Contrast between the whole milk of the evening milking vs. the whole milk of the morning milking.

${ }^{3}$ Contrast between milk collected from the vat (mixture of the creamed evening milk and the whole morning milk) vs. the mean of the creamed evening milk and the whole morning milk.

${ }^{4} \mathrm{SCS}=\log _{2}(\mathrm{SCC} / 100,000)+3$.

${ }^{5} \mathrm{MCP}=$ milk coagulation properties; $\mathrm{RCT}=$ rennet coagulation time of samples coagulating within 45 min from enzyme addition; $\mathrm{k}_{20}=$ curdfirming time of samples reaching $20 \mathrm{~mm}$ of firmness within $45 \mathrm{~min}$ from enzyme addition; $\mathrm{a}_{30}=$ curd firmness 30 min after enzyme addition.

${ }^{6} \mathrm{CF}_{\mathrm{t}}$ modeling $=$ modeling of the 180 curd firmness observations collected for each milk sample; $\mathrm{CF}_{\mathrm{P}}=$ potential asymptotical curd firmness in absence of syneresis; $\mathrm{k}_{\mathrm{CF}}=$ curd firming instant rate constant; $\mathrm{k}_{\mathrm{SR}}=$ curd syneresis instant rate constant; $\mathrm{RCT}_{\mathrm{eq}}=$ rennet coagulation time estimated through individual curd firming equation; $\mathrm{CF}_{\max }=$ maximum curd firmness value; $\mathrm{t}_{\max }=$ time at $\mathrm{CF}_{\max }$.

${ }^{*} P<0.05 ;{ }^{* *} P<0.01 ;{ }^{* * *} P<0.001$. 


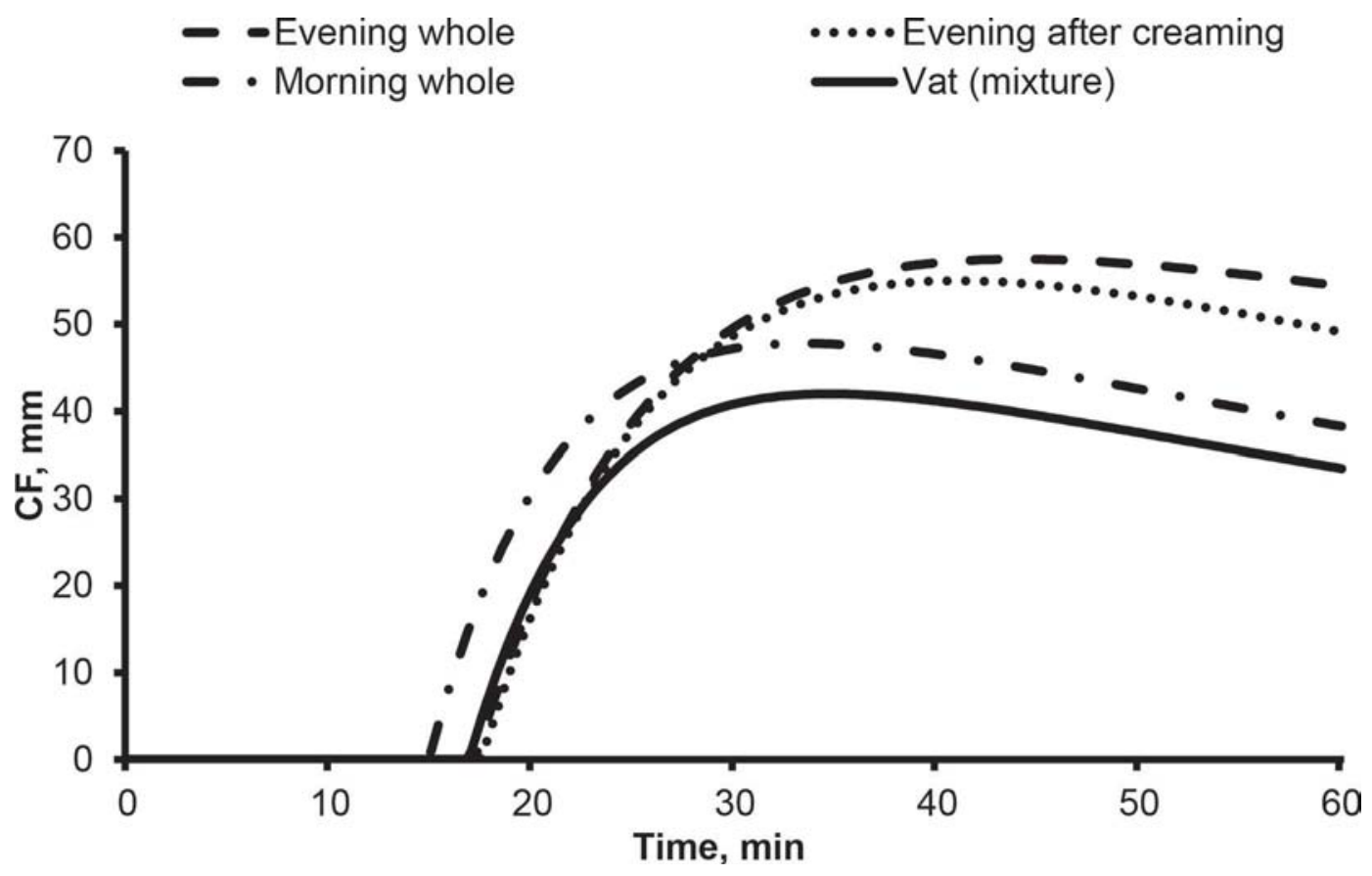

Figure 3. Evolution of curd firmness (CF) process obtained from milk samples collected during summer transhumance: whole evening, evening after creaming, whole morning, and vat (mixture) milks.

cheese yield (cubic, from 9.73 to $5.57 \%$ ) and cream yield (linear, from 14.95 to $14.45 \%$ ) due to the high milk fat content at first cheesemaking date. Variation in yields over the summer transhumance was due, in part, to the observed changes in milk composition (especially fat and casein content, Figure 1) consequent to advancing lactation stage, as well as changes of season (VerdierMetz et al., 1998; Zendri et al., 2016a). Water retention in fresh products (cream, curd, and ricotta) is also an important component of yields, especially of ricotta (Table 6). However, the yields of the different products depend first of all on the protein and fat content of milk (Verdier-Metz et al., 2001) and on the recovery of milk nutrients in dairy products compared with the loss in wasted effluents (whey and scotta).

Milk nutrient recoveries in cream, curd, and ricotta are also shown in Table 6. Natural creaming yields cream with a $38 \%$ of milk fat content, representing about $10 \%$ of milk solids and $18 \%$ of milk energy. No information on the efficiency of natural creaming in traditional Alpine cheesemaking is available.

During the second stage of processing, partial skim milk is used to produce fresh cheese containing about $85 \%$ of milk fat and $78 \%$ of milk proteins, representing almost $50 \%$ of milk TS and $58 \%$ of processed milk energy. Little specific information is available on these technological traits in Malga cheese production, although more data are available on cheese-quality traits (Buchin et al., 1999; Bovolenta et al., 2009; Hurtaud et al., 2009). Taking into account the partial defatting of milk, the above recovery rates of fresh cheese may be considered normal, as they are similar to those obtained in the lowlands under very different conditions with milk from cows of Alpine breeds (Verdier et al., 1995; Martin et al., 2009; Cecchinato and Bittante, 2016).

Seasonal variations in fat $(P<0.001)$ and protein $(P<0.01)$ recoveries in cheese contributed to the TS and energy recoveries, which exhibited an almost linear upward trend during the summer grazing season (Table 6 and Figure 4b). Although few studies have examined experimentally measured cheesemaking technological parameters for mountain cheeses, predictions of cheese yields (fresh and solid cheese yields, and cheese water retention) and nutrient recoveries in curd (fat, protein, TS, and energy) have been made through Fourier transform infrared spectral analysis (Ferragina et al., 2013, 2015) of samples collected for milk recordings on permanent mountain farms (Cecchinato et al., 2015) and temporary summer Alpine farms (Zendri et al., 2016b). In both cases, the predicted average values of the various traits, and the pattern during summer transhumance in the latter case, were very similar to the values measured in the present study, confirming the good prediction ability of Fourier transform infrared calibrations.

In the third stage, production of ricotta from milk whey processing, the fresh product yield (5\%), was about three-quarters dependent on water retention and 
one-quarter dependent on solids (Table 6). This last figure represented almost all the milk fat present in whey (lost during cheesemaking) and almost half the protein (mainly whey proteins). On the whole, TS recovered in ricotta were $14 \%$ of whey solids and $23 \%$ of whey energy (Table 6). No information is available on ricotta production on temporary summer Alpine farms. The fluctuations in these traits in ricotta-making recorded during summer transhumance are shown in Figure 4b.

Through the analysis of correlation between cheese yield and pasture productivity and quality, it appears there may be a negative relationship between the quantity of DM available in the pasture and cheese yield expressed in terms of fresh cheese, cheese DM, or moisture retained in the cheese (Table 7 ). This does not seem to be due to the recovery efficiency of the various nutrients in cheese, but rather to a possible reduction in milk fat and TS content (Table 4). The correlation between the lipid content of pasture and of milk seems also to be the main explanation for the link between the ether extract content of grass and the 3 cheese yields examined (Table 7). The yields and nutrient recoveries of ricotta did not seem to be correlated with the quantity and quality of available grass. We found no information on these matters in the literature.

\section{Flow of Milk Nutrients to Different Dairy Products and By-Products}

To obtain a clear picture of the entire traditional cheese- and ricotta-making procedures adopted by temporary summer farms on Alpine pastures, the chemical compositions of the processed fluids (vat milk, whey, and scotta) of the fresh products (cream, curd, and ricotta) and ripened cheeses (after 6 or 12 mo of ripening) are reported in Table 8. Schematization of the whole flow process from milk to dairy products and byproducts through the different stages in terms of total weight, milk fat, milk protein, and total solids is shown in Figure 5.

At the end of the process, the saleable products obtained (which include cream and ricotta) represent about $20 \%$ of milk weight, the other $80 \%$ being the final by-product (scotta). Moving from fresh weight to nutrient recovery, it is clear that cheesemaking has a much more important role. The final recovery of milk

Table 6. Analysis of variance for yields, nutrient and energy recoveries of creaming, cheese-, and ricotta-making observed every 2 wk $(\mathrm{n}=7$ ) during summer transhumance

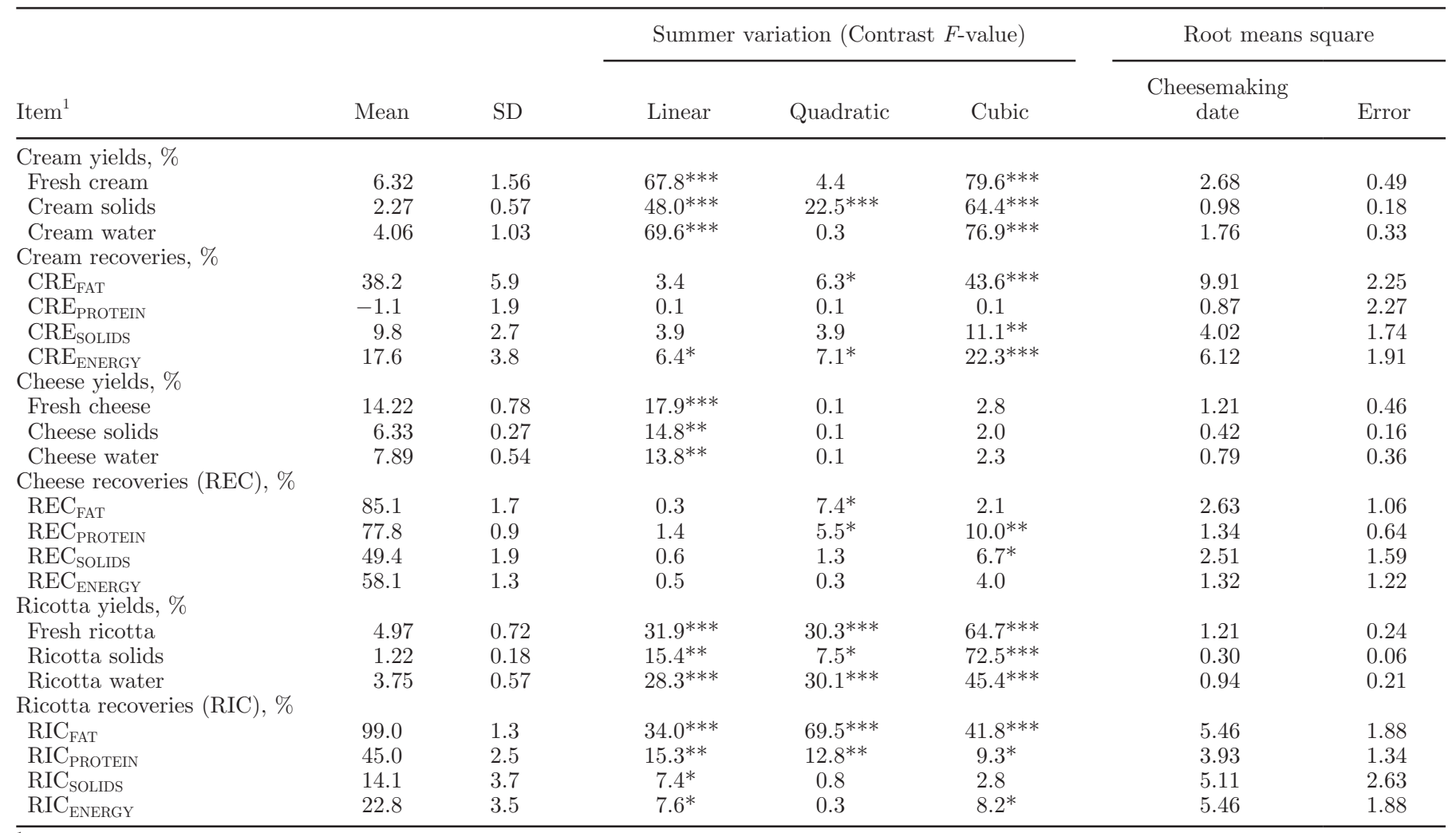

${ }^{1}$ The nutrient recoveries in cheesemaking (REC) and ricotta-making (RIC) were calculated as described in detail by Cipolat-Gotet et al. (2013). ${ }^{*} P<0.05 ;{ }^{* *} P<0.01 ;{ }^{* * *} P<0.001$. 


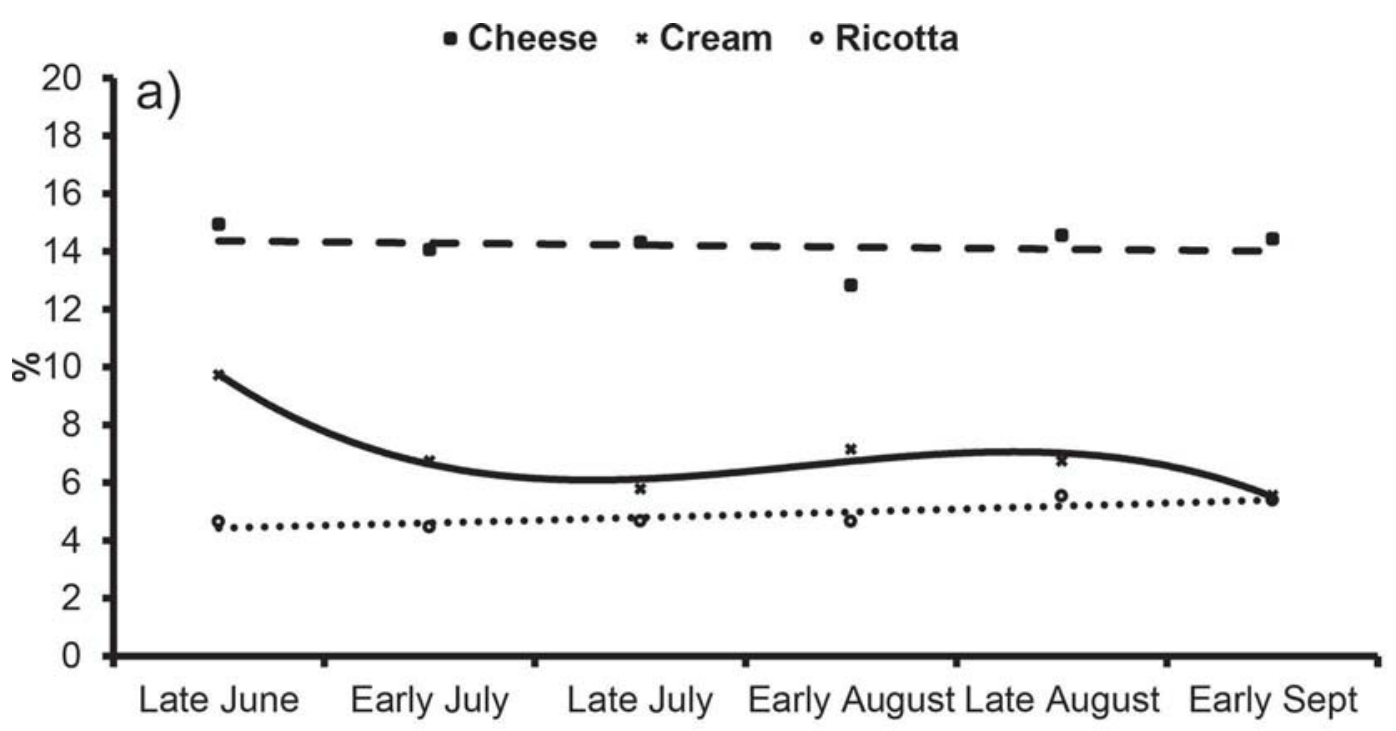

oRECenergy $\triangle$ RECsolids - RICenergy $\bullet$ RICsolids $\times$ CREenergy $\square$ CREsolids

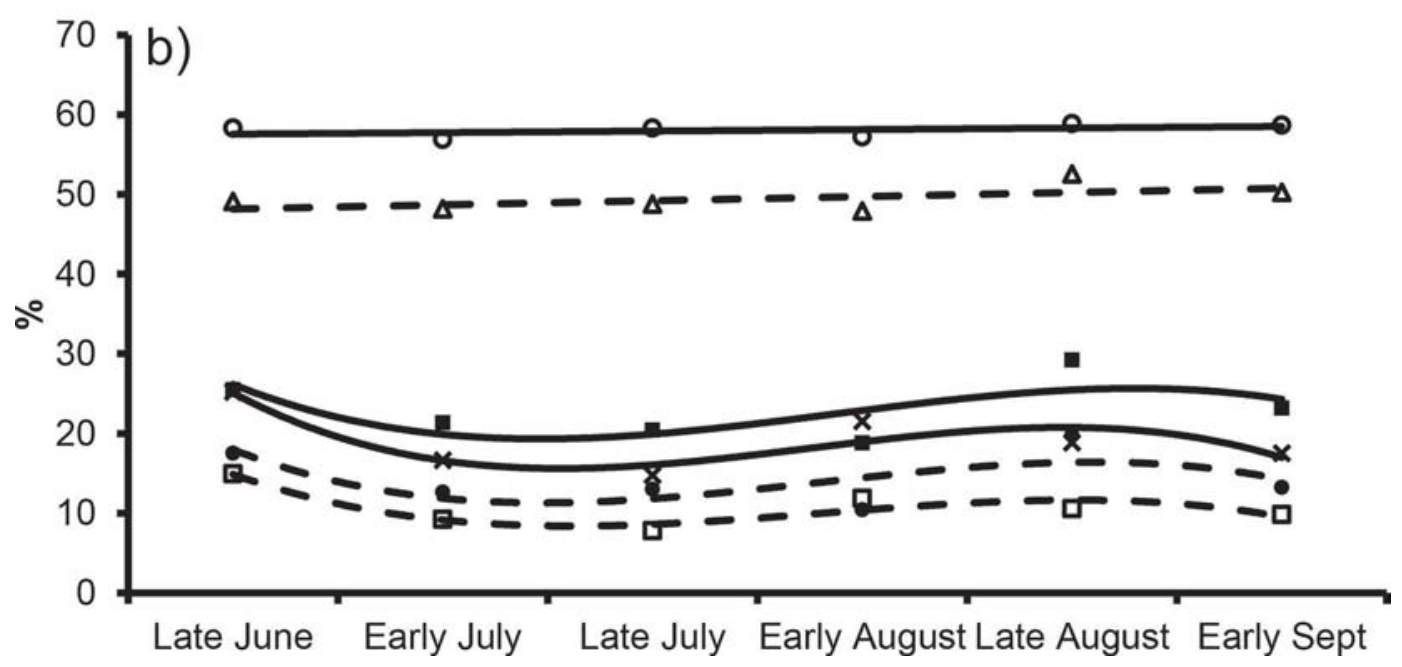

Figure 4. Evolution (LSM) of (a) yields, and (b) energy and solids recoveries in cheese (REC), cream (CRE), and ricotta (RIC) during summer pasture.

fat is close to $100 \%$, with about two-thirds retained in Malga cheese and one-third in cream and ricotta. In the case of milk protein, the proportion lost in the scotta is about one-eighth, as almost $80 \%$ is retained in Malga cheese and $10 \%$ in ricotta. The presence of most of the lactose and minerals in the scotta reduced the overall TS recovery to about $60 \%$, with almost $50 \%$ represented by Malga cheese and the remainder by cream and ricotta.

Cheeses produced according to traditional procedures from raw milk obtained from cows grazing on Alpine pastures are easily distinguishable from the industrial products of the lowlands, especially in terms of their fatty acid profile (Collomb et al., 2002; Coppa et al., 2011), color, and flavor (Carpino et al., 2004). Significant production of Malga cheeses in situ occurs on temporary summer farms even now. According to Zendri et al. (2013), summer pastures used by dairy cows account for two-thirds of all grazed Alpine pastures, and about one-third of temporary summer farms still produce cheese and other dairy products at an average altitude of 1,661 $\pm 235 \mathrm{~m}$ above sea level. Evidence of the importance of in situ cheese- and ricotta-making in the Alps comes from the fact that many of these 
Table 7. Pearson correlations between quantity and quality of the grass available in the Alpine pasture the day before each experimental cheesemaking and the technological properties of cheese- and ricotta-making in the temporary summer farm

\begin{tabular}{|c|c|c|c|c|}
\hline \multirow[b]{2}{*}{ Item $^{1}$} & \multirow{2}{*}{$\begin{array}{c}\text { Grass available, } \\
\text { t/ha (DM) }\end{array}$} & \multicolumn{3}{|c|}{ Grass composition, $\%$ of DM } \\
\hline & & $\mathrm{CP}$ & Ether extract & NDF \\
\hline \multicolumn{5}{|l|}{ Cheese yields, \% } \\
\hline Fresh cheese & -0.71 & 0.44 & $0.92 * *$ & -0.42 \\
\hline Cheese solids & -0.73 & 0.43 & $0.93^{* *}$ & -0.47 \\
\hline Cheese water & -0.69 & 0.42 & $0.92^{* *}$ & -0.37 \\
\hline \multicolumn{5}{|c|}{ Cheese recoveries (REC), \% } \\
\hline $\mathrm{REC}_{\mathrm{FAT}}$ & 0.33 & 0.31 & -0.49 & -0.13 \\
\hline $\mathrm{REC}_{\text {PROTEIN }}$ & -0.25 & -0.35 & 0.61 & 0.35 \\
\hline $\mathrm{REC}_{\text {SOLIDS }}$ & -0.18 & -0.31 & 0.57 & 0.40 \\
\hline $\mathrm{REC}_{\text {ENERGY }}$ & -0.32 & -0.06 & 0.71 & 0.35 \\
\hline \multicolumn{5}{|c|}{ Ricotta yields, \% } \\
\hline Fresh ricotta & 0.05 & -0.25 & 0.31 & 0.44 \\
\hline Ricotta solids & -0.19 & -0.29 & 0.55 & 0.41 \\
\hline Ricotta water & 0.13 & -0.22 & 0.23 & 0.43 \\
\hline \multicolumn{5}{|c|}{ Ricotta recoveries (RIC), \% } \\
\hline $\mathrm{RIC}_{\mathrm{FAT}}$ & -0.17 & 0.19 & -0.31 & -0.20 \\
\hline RIC $_{\text {PROTEIN }}$ & 0.05 & 0.45 & 0.39 & -0.05 \\
\hline RIC $_{\text {SOLIDS }}$ & -0.21 & 0.38 & 0.62 & -0.17 \\
\hline RIC $_{\text {ENERGY }}$ & -0.31 & 0.18 & 0.68 & -0.05 \\
\hline
\end{tabular}

${ }^{1}$ The nutrient recoveries in cheese-making (REC) and ricotta-making (RIC) were calculated as described in detail by Cipolat-Gotet et al. (2013).

$* * P<0.01$.

Table 8. Composition of processed fluids, fresh products, and cheeses obtained from the seven experimental cheese- and ricotta-making during summer transhumance

\begin{tabular}{|c|c|c|c|c|c|c|c|}
\hline Item & $\mathrm{pH}$ & $\begin{array}{c}\text { Fat, } \\
\%\end{array}$ & $\begin{array}{c}\text { Protein, } \\
\%\end{array}$ & $\begin{array}{c}\text { Lactose } \\
\%\end{array}$ & $\begin{array}{l}\mathrm{TS}, \\
\%\end{array}$ & $\begin{array}{l}\mathrm{SCS},{ }^{1} \\
\mathrm{U} / \mathrm{mL}\end{array}$ & $\begin{array}{c}\text { Salt, } \\
\%\end{array}$ \\
\hline \multicolumn{8}{|l|}{ Processed fluids (LSM) } \\
\hline Vat milk $(\mathrm{A})$ & 6.51 & 3.37 & 3.70 & 4.89 & 12.7 & 3.59 & - \\
\hline $\operatorname{Scotta}^{2}(\mathrm{C})$ & 5.70 & 0.01 & 0.56 & 5.05 & 6.7 & 0.08 & - \\
\hline \multicolumn{8}{|l|}{ Contrasts (F-value) } \\
\hline Vat milk vs. whey (A vs. B) & $10.8^{* * *}$ & $>100 * * *$ & $>100 * * *$ & 2.9 & $>100 * * *$ & $46.8^{* * *}$ & - \\
\hline Error & 0.199 & 0.120 & 0.052 & 0.192 & 0.300 & 0.472 & - \\
\hline \multicolumn{8}{|l|}{ Fresh products (LSM) } \\
\hline Cream (D) & 6.51 & 28.1 & 3.2 & - & 36.3 & - & - \\
\hline Curd (E) & 6.59 & 20.4 & 20.2 & - & 44.4 & - & - \\
\hline Ricotta (F) & 6.14 & 8.7 & 8.8 & - & 24.7 & - & - \\
\hline \multicolumn{8}{|l|}{ Contrasts (F-value) } \\
\hline \multicolumn{8}{|l|}{ Cheeses (LSM) } \\
\hline Curd (E) & 6.59 & 20.4 & 20.2 & - & 44.4 & - & 0.88 \\
\hline Cheese ripened 6 mo $(\mathrm{G})$ & 5.49 & 29.4 & 29.9 & - & 66.0 & - & 2.02 \\
\hline Cheese ripened $12 \mathrm{mo}(\mathrm{H})$ & 5.83 & 30.1 & 32.2 & - & 69.1 & - & 2.15 \\
\hline \multicolumn{8}{|l|}{ Contrasts (F-value) } \\
\hline Curd vs. cheeses (E vs. $\mathrm{G}+\mathrm{H}$ ) & $>100 * * *$ & $>100^{* * *}$ & $>100 * * *$ & - & $>100^{* * *}$ & - & $>100 * * *$ \\
\hline 6 mo vs. 12 mo ripening ( $\mathrm{G}$ vs. $\mathrm{H}$ ) & $49.5^{* * *}$ & $4.3^{*}$ & $51.7^{* * *}$ & - & $32.5^{* * *}$ & - & $13.8^{* * *}$ \\
\hline \multicolumn{8}{|l|}{ Root means square } \\
\hline Cheesemaking date & 0.097 & 0.292 & 0.690 & - & 0.278 & - & 0.017 \\
\hline Error & 0.088 & 0.622 & 0.598 & - & 1.021 & - & 0.063 \\
\hline
\end{tabular}




\section{BYPRODUCTS:}

\section{BYPRODUCTS:}

Evening milking

Morning milking

Natural creaming

Milk mixing

Cheese-making

Ricotta-making

Cheese ripening

ond

Chese

Ricotıa-making

\begin{tabular}{ll} 
Weight & $83 \mathrm{~kg}$ \\
Fat & $12 \%$ \\
Protein & $22 \%$ \\
Total solids & $48 \%$ \\
\hline
\end{tabular}

\section{Scotta}

\begin{tabular}{|c|c|}
\hline Weight & $79 \mathrm{~kg}$ \\
\hline Fat & $1 \%$ \\
\hline Protein & $12 \%$ \\
\hline & 410 \\
\hline
\end{tabular}

MILK:

PRODUCTS:

\section{Whole milk}

\begin{tabular}{ll} 
Weight & $\mathbf{5 0} \mathbf{~ k g}$ \\
Fat & $\mathbf{4 9} \%$ \\
Protein & $\mathbf{5 0} \%$ \\
Total solids & $\mathbf{5 0} \%$ \\
\hline
\end{tabular}

\begin{tabular}{|ll|}
\hline \multicolumn{2}{|c|}{ Whole milk } \\
Weight & $\mathbf{5 0} \mathrm{kg}$ \\
Fat & $\mathbf{5 1} \%$ \\
Protein & $\mathbf{5 0} \%$ \\
Total solids & $\mathbf{5 0} \%$ \\
\hline
\end{tabular}

Skimmed milk
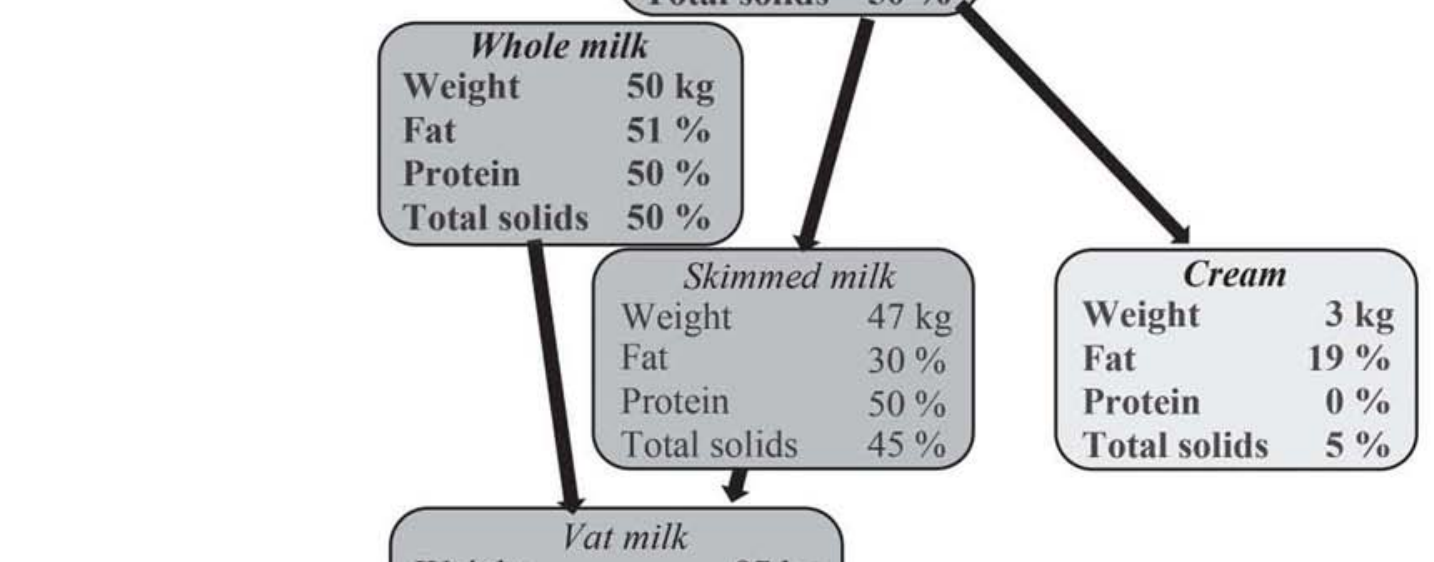

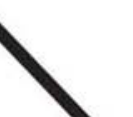

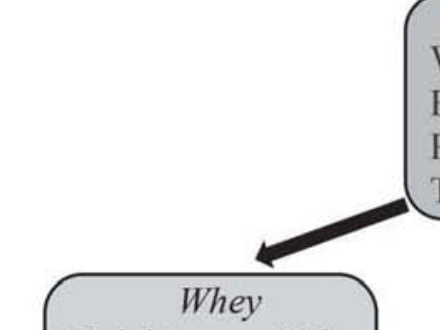

Weight Vat milk

Weight

Fat

Protein

Total solids

Fresh cheese

Weight $\quad 14 \mathrm{~kg}$

Fat $\quad 69 \%$

Protein $\quad \mathbf{7 8} \%$

Total solids $47 \%$

\begin{tabular}{lr} 
Weight & $4 \mathrm{~kg}$ \\
Fat & $11 \%$ \\
Protein & $10 \%$ \\
Total solids & $7 \%$ \\
\hline
\end{tabular}

Ripened cheese (6 mo)

Weight $\quad 12 \mathrm{~kg}$

Fat $\quad 69 \%$

Protein $\quad \mathbf{7 8} \%$

Total solids $\quad 47 \%$

\begin{tabular}{ll}
\hline \multicolumn{2}{|l}{ Ripened cheese $(12 \mathrm{mo})$} \\
Weight & $11 \mathrm{~kg}$ \\
Fat & $69 \%$ \\
Protein & $78 \%$ \\
Total solids & $47 \%$ \\
\hline
\end{tabular}

Figure 5. Flow of average weight, fat, protein, and TS of different dairy products and by-products obtained from creaming, cheese-, and ricotta-making. 
temporary farms are involved in agritourism through direct sales of their own products as well as meals made using these products (Zendri et al., 2013).

\section{CONCLUSIONS}

This work explored the links between the efficiency of traditional cheese- and ricotta-making and the output of dairy products obtained during the grazing season on temporary highland farms. To our knowledge, this is the first time that cheese- and ricotta-making processes during summer transhumance have been characterized by collecting different dairy products (milk, cream, whey, scotta, ricotta, curd, and ripened cheese) and monitoring milk nutrients flow during all steps of processing. The results reported in this experiment suggest sizeable variations in the chemical compositions and nutrient recoveries of cheese, ricotta, and cream during summer transhumance. In particular, we confirmed the decrease in milk yield from cows after moving to the Alpine pastures and during the summer grazing season, probably due to nutrient imbalance, but we also found partial recovery of productive functions after returning to the lowland permanent farms. Monitoring of technological characteristics of milk during summer grazing revealed variations that partly correlated with the quantity and quality of forage available in the areas grazed by the cows. The traditional cheese- and ricotta-making procedures used on the temporary highland farms during summer were characterized in terms of cream, cheese, and ricotta yields and nutrient recoveries across the various stages. The overall process could be considered efficient, as it allows recovery of about $20 \%$ of milk weight, $60 \%$ of milk TS, $88 \%$ of milk protein, and almost $100 \%$ of milk fat in the fresh products. Moreover, transhumance practices maximize resource exploitation through grazing and support traditional activities. Indeed, milk produced on temporary highland farms can be used to produce typical cheeses and ricotta with an added value linked to terroir and historical production traditions. These findings may be relevant for greater appreciation of the quality of dairy products from upland farms operating extensive farming systems.

\section{ACKNOWLEDGMENTS}

The authors thank Autonomous Province of Trento (Italy) for funding the research, and gratefully acknowledge Simone Valorz (Agriculture and Veterinary Medicine School of the University of Padova, Legnaro, Padova, Italy) for collaboration in recording data, collection and analyses of samples. The authors wish also to thank Francesco Gubert, Silvia Schiavon, and
Angelo Pecile (Edmund Mach Foundation, San Michele all'Adige, Trento, Italy) for cheese ripening.

\section{REFERENCES}

Agabriel, C., J. B. Coulon, C. Journal, C. Sibra, and H. Albouy. 1999. Variabilité des caractéristiques des fromages saint-nectaire fermiers: Relations avec la composition du lait et les conditions de production. Lait 79:291-302.

Ali, A. K. A., and G. E. Shook. 1980. An optimum transformation for somatic cell concentration in milk. J. Dairy Sci. 63:487-490.

AOAC International. 2000. Official Methods of Analysis. 17th ed. AOAC International, Arlington, VA.

Battaglini, L., S. Bovolenta, F. Gusmeroli, S. Salvador, and E. Sturaro. 2014. Environmental sustainability of Alpine livestock farms. Ital. J. Anim. Sci. 13:3155.

Bertoni, G., L. Calamari, and M. G. Maianti. 2001. Producing specific milk for specialty cheeses. Proc. Nutr. Soc. 60:231-246.

Bittante, G. 2011. Modeling rennet coagulation time and curd firmness of milk. J. Dairy Sci. 94:5821-5832.

Bittante, G., C. Cipolat-Gotet, F. Malchiodi, E. Sturaro, F. Tagliapietra, S. Schiavon, and A. Cecchinato. 2015. Effect of dairy farming system, herd, season, parity and days in milk on modeling of the coagulation, curd firming and syneresis of bovine milk. J. Dairy Sci. 98:2759-2774.

Bittante, G., B. Contiero, and A. Cecchinato. 2013. Prolonged observation and modelling of milk coagulation, curd firming, and syneresis. Int. Dairy J. 29:115-123.

Bovolenta, S., M. Corazzin, E. Saccà, F. Gasperi, F. Biasioli, and W. Ventura. 2009. Performance and cheese quality of Brown cows grazing on mountain pastures fed two different levels of supplementation. Livest. Sci. 124:58-65.

Bovolenta, S., E. Saccà, W. Ventura, and E. Piasentier. 2002. Effect of type and level of supplement on performance of dairy cows grazing on alpine pasture. Ital. J. Anim. Sci. 1:255-263.

Bovolenta, S., W. Ventura, E. Piasentier, and F. Malossini. 1998. Supplementation of dairy cows grazing an alpine pasture: Effect of concentrate level on milk production, body condition and rennet coagulation properties. Ann. Zootech. 47:169-178.

Buchin, S., B. Martin, D. Dupont, A. Bornard, and C. Achilleos. 1999. Influence of the composition of Alpine highland pasture on the chemical, rheological and sensory properties of cheese. J. Dairy Res. 66:579-588.

Buchin, S., B. Martin, and A. Hauwuy. 2006. Pasture and cheese diversity in French Northern Alps. Pages 155-130 in Livestock Farming Systems. Product Quality Based on Local Resources Leading to Improved Sustainability. EAAP publication, vol. 118. Wageningen Academic Publishers, Wageningen, the Netherlands.

Caplan, Z., C. Melilli, and D. M. Barbano. 2013. Gravity separation of fat, somatic cells, and bacteria in raw and pasteurized milks. J. Dairy Sci. 96:2011-2019.

Carpino, S., S. Mallia, S. La Terra, C. Melilli, G. Licitra, T. E. Acree, D. M. Barbano, and P. J. Van Soest. 2004. Composition and aroma compounds of Ragusano cheese: Native pasture and Total Mixed Rations. J. Dairy Sci. 87:816-830.

Cecchinato, A., A. Albera, C. Cipolat-Gotet, A. Ferragina, and G. Bittante. 2015. Genetic parameters of cheese yield and curd nutrient recovery or whey loss traits predicted using Fourier-transform infrared spectroscopy of samples collected during milk recording on Holstein, Brown Swiss, and Simmental dairy cows. J. Dairy Sci. 98:4914-4927.

Cecchinato, A., and G. Bittante. 2016. Genetic, herd, and environmental relationships of different measures of individual cheese yield and curd nutrients recovery/whey loss and coagulation properties of bovine milk. J. Dairy Sci. 99:1975-1989. http://dx.doi. org/10.3168/jds.2015-9629.

Cecchinato, A., C. Cipolat-Gotet, J. Casellas, M. Penasa, A. Rossoni, and G. Bittante. 2013. Genetic analysis of rennet coagulation time, curd-firming rate, and curd firmness assessed over an extended 
testing period using mechanical and near-infrared instruments. J. Dairy Sci. 96:50-62.

Cipolat-Gotet, C., A. Cecchinato, M. De Marchi, and G. Bittante. 2013. Factors affecting variation of different measures of cheese yield and milk nutrient recovery from an individual model cheesemanufacturing process. J. Dairy Sci. 96:7952-7965.

Collomb, M., U. Bütikofer, R. Sieber, B. Jeangros, and J. O. Bosset. 2002. Correlations between fatty acids in cows' milk fat produced in the lowland, mountain and highlands of Switzerland and botanical composition of the fodder. Int. Dairy J. 12:661-666.

Coppa, M., A. Ferlay, F. Monsallier, I. Verdier-Metz, P. Pradel, R. Didienne, A. Farruggia, M. C. Montel, and B. Martin. 2011. Milk fatty acid composition and cheese texture and appearance from cows fed hay or different grazing systems on upland pastures. J. Dairy Sci. 94:1132-1145.

Dewhurst, R. J., K. J. Shingfield, M. R. F. Lee, and N. D. Scollan. 2006. Increasing the concentrations of beneficial polyunsaturated fatty acids in milk produced by dairy cows in high-forage systems. Anim. Feed Sci. Technol. 131:168-206.

Euber, J. R., and J. R. Brunner. 1984. Reexamination of fat globule clustering and creaming in cow milk. J. Dairy Sci. 67:2821-2832.

Feligni, M., E. Brambati, S. Panelli, M. Ghitti, R. Sacchi, E. Capelli, and C. Bonacina. 2014. One-year investigation of Clostridium spp. occurrence in raw milk and curd of Grana Padano cheese by the automated ribosomial intergenic spacer analysis. Food Contr. 42:71-77.

Ferlay, A., B. Martin, Ph. Pradel, J. B. Coulon, and Y. Chilliard. 2006. Influence of grass-based diets on milk fatty acid composition and milk lipolytic system in Tarentaise and Montbeliarde cow breeds. J. Dairy Sci. 89:4026-4041.

Ferragina, A., C. Cipolat-Gotet, A. Cecchinato, and G. Bittante. 2013 The use of Fourier-transform infrared spectroscopy to predict cheese yield and nutrient recovery or whey loss traits from unprocessed bovine milk samples. J. Dairy Sci. 96:7980-7990.

Ferragina, A., G. de los Campos, A. I. Vazquez, A. Cecchinato, and G. Bittante. 2015. Bayesian regression models outperform partial least squares methods for predicting milk components and technological properties using infrared spectral data. J. Dairy Sci. 98:8133-8151.

Gorlier, A., M. Lonati, M. Renna, C. Lussiana, G. Lombardi, and L. M. Battaglini. 2012. Changes in pasture and cow milk compositions during a summer transhumance in the western Italian Alps. J. Appl. Bot. Food Qual. 85:216-223.

Haddaway, N. R., D. Styles, and A. S. Pullin. 2013. Environmental impacts of farm land abandonment in high altitude/mountain regions: a systematic map of the evidence. Environ. Evid. 2:18.

Hurtaud, C., J. L. Peyraud, G. Michel, D. Berthelot, and L. Delaby 2009. Winter feeding systems and dairy cow breed have an impact on milk composition and flavour of two Protected Designation of Origin French cheeses. Animal 3:1327-1338.

Leiber, F., M. Kreuzer, H. Leuenberger, and H.-R. Wettstein. 2006. Contribution of diet type and pasture conditions to the influence of high altitude grazing on intake, performance and composition and renneting properties of the milk of cows. Anim. Res. 55:37-53.

Martin, B., D. Pomiès, P. Pradel, I. Verdier-Metz, and B. Rémond. 2009. Yield and sensory properties of cheese made with milk from Holstein or Montbéliarde cows milked twice or once daily. J. Dairy Sci. 92:4730-4737.

Martin, B., I. Verdier-Metz, S. Buchin, C. Hurtaud, and J. B. Coulon. 2005. How does the nature of forages and pastures diversity influ- ence the sensory quality of dairy livestock products? J. Anim. Sci $81: 205-212$

McMahon, D. J., and R. J. Brown. 1982. Evaluation of Formagraph for comparing rennet solutions. J. Dairy Sci. 65:1639-1642.

NRC. 2001. Nutrient Requirements of Dairy Cattle. 7th rev. ed. Natl. Acad. Sci., Washington, DC.

Orlandi, D., F. Clementel, F. Scartezzini, and A. Floris. 2000. Caratterizzazione e cartografia dei pascoli di una malga alpina (Malga Juribello - Trento). Comunicazioni di Ricerca ISAFA. 1:1-24.

Penati, C., P. B. M. Berentsen, A. Tamburini, A. Sandrucci, and I. J. M. de Boer. 2011. Effect of abandoning highland grazing on nutrient balances and economic performance of Italian Alpine dairy farms. Livest. Sci. 139:142-149.

Pintado, M. E., A. C. Macedo, and F. X. Malcata. 2001. Review: Technology, chemistry and microbiology of whey cheeses. Food Sci Technol. Int. 7:105-116.

Politis, I., and K. F. Ng-Kwai-Hang. 1988. Effects of somatic cell count and milk composition on cheese composition and cheese making efficiency. J. Dairy Sci. 71:1711-1719.

Romanzin, A., M. Corazzin, E. Piasentier, and S. Bovolenta. 2013. Effect of rearing system (mountain pasture vs. indoor) of Simmental cows on milk composition and Montasio cheese characteristics. J. Dairy Res. 80:390-399.

Stocco, G., C. Cipolat-Gotet, A. Cecchinato, L. Calamari, and G. Bittante. 2015. Milk skimming, heating, acidification, lysozyme, and rennet affect the pattern, repeatability, and predictability of milk coagulation properties and of curd-firming model parameters: A case study of Grana Padano. J. Dairy Sci. 98:5052-5067.

Sturaro, E., E. Marchiori, G. Cocca, M. Penasa, M. Ramanzin, and G. Bittante. 2013. Dairy systems in mountainous areas: Farm animal biodiversity, milk production and destination, and land use. Livest. Sci. 158:157-168.

Van Soest, P. J., J. B. Robertson, and B. A. Lewis. 1991. Methods for dietary fiber, neutral detergent fiber, and non-starch polysaccarides in relation to animal nutrition. J. Dairy Sci. 74:3583-3597.

Verdier, I., J. B. Coulon, P. Pradel, and J. L. Berdagué. 1995. Effect of forage type and cow breed on the characteristics of matured SaintNectaire cheeses. Lait 75:523-533.

Verdier-Metz, I., J. B. Coulon, and P. Pradel. 2001. Relationship between milk fat and protein contents and cheese yield. Anim. Res. $50: 365-371$

Verdier-Metz, I., J. B. Coulon, P. Pradel, C. Viallon, and J. L. Berdaguè. 1998. Effect of forage conservation (hay or silage) and cow breed on the coagulation properties of milks and on the characteristics of ripened cheeses. J. Dairy Res. 65:9-21.

Zendri, F., M. Ramanzin, G. Bittante, and E. Sturaro. 2016a. Transhumance of dairy cows to highland summer pastures interacts with breed to influence body condition, milk yield, and quality. Ital. J. Anim. Sci. http://dx.doi.org/10.1080/1828051X.2016.1217176.

Zendri, F., M. Ramanzin, C. Cipolat-Gotet, and E. Sturaro. 2016b. Variation of milk coagulation properties, cheese yield, and nutrients recovery in curd of cows of different breeds before, during and after transhumance to highland summer pastures. J. Dairy Res. $10.1017 /$ S0022029916000583.

Zendri, F., E. Sturaro, and M. Ramanzin. 2013. Highland summer pastures play a fundamental role for dairy systems in Italian Alpine region. Agric. Conspec. Sci. 78:295-299. 